Provided for non-commercial research and education use. Not for reproduction, distribution or commercial use.

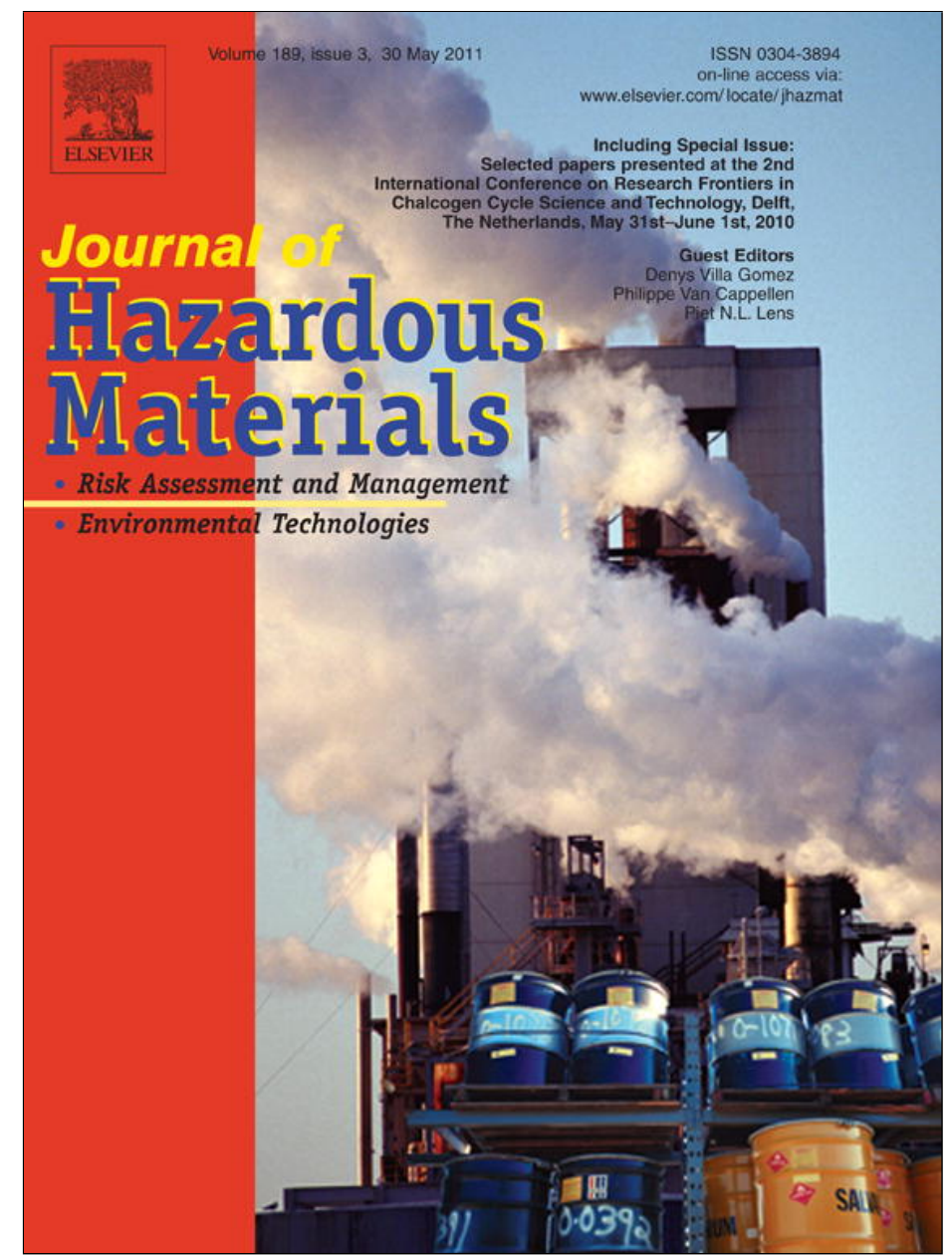

This article appeared in a journal published by Elsevier. The attached copy is furnished to the author for internal non-commercial research and education use, including for instruction at the authors institution and sharing with colleagues.

Other uses, including reproduction and distribution, or selling or licensing copies, or posting to personal, institutional or third party websites are prohibited.

In most cases authors are permitted to post their version of the article (e.g. in Word or Tex form) to their personal website or institutional repository. Authors requiring further information regarding Elsevier's archiving and manuscript policies are encouraged to visit:

http://www.elsevier.com/copyright 


\title{
Different strategies for recovering metals from CARON process residue
}

\author{
G. Cabrera ${ }^{\mathrm{a}, *}$, J.M. Gómez ${ }^{\mathrm{a}}$, I. Hernández ${ }^{\mathrm{b}}, \mathrm{O}$ Coto $^{\mathrm{b}}$, D. Cantero ${ }^{\mathrm{a}}$ \\ a Biological and Enzymatic Reactors Group, Department of Chemical Engineering and Food Technology, Faculty of Sciences, University of Cadiz, Spain \\ ${ }^{\mathrm{b}}$ Laboratory of Metals, Department of Microbiology, Faculty of Biology, University of Havana, Cuba
}

\section{A R T I C L E I N F O}

\section{Article history:}

Received 19 January 2011

Received in revised form 3 March 2011

Accepted 13 March 2011

Available online 21 March 2011

\section{Keywords:}

Acidithiobacillus thiooxidans

Heavy metals

CARON process residue

Leaching

\begin{abstract}
A B S T R A C T
The capacity of Acidithiobacillus thiooxidans DMS 11478 to recover the heavy metals contained in the residue obtained from the CARON process has been evaluated. Different bioreactor configurations were studied: a two-stage batch system and two semi-continuous systems (stirred-tank reactor leaching and column leaching). In the two-stage system, 46.8\% Co, 36.0\% Mg, 26.3\% Mn and 22.3\% Ni were solubilised after $6 \mathrm{~h}$ of contact between the residue and the bacteria-free bioacid. The results obtained with the stirred-tank reactor and the column were similar: $50 \%$ of the $\mathrm{Mg}$ and $\mathrm{Co}$ and $40 \%$ of the $\mathrm{Mn}$ and $\mathrm{Ni}$ were solubilised after thirty one days. The operation in the column reactor allowed the solid-liquid ratio to be increased and the $\mathrm{pH}$ to be kept at low values $(<1.0)$. Recirculation of the leachate in the column had a positive effect on metal removal; at sixty five days (optimum time) the solubilisation levels were as follows: $86 \% \mathrm{Co}, 83 \% \mathrm{Mg}, 72 \% \mathrm{Mn}$ and $\mathrm{Ni}, 62 \% \mathrm{Fe}$ and $23 \% \mathrm{Cr}$. The results corroborate the feasibility of the systems studied for the leaching of metals from CARON process residue and these methodologies can be considered viable for the recovery of valuable metals.
\end{abstract}

(c) 2011 Elsevier B.V. All rights reserved.

\section{Introduction}

Laterites are iron-nickel oxides associated with other metals and they are especially common in warm climates with abundant rainfall. Cuba has the second-largest nickel and cobalt reserves in the world [1]. These reserves include laterite deposits in the country's north-eastern region (Moa, Holguín) and these materials are processed by ammonium carbonate technology (CARON) to extract the nickel. This process generates a solid residue with a complex structure that is physically characterised by its black colour, semi-metallic lustre, fine particle size and predominantly magnetic nature [2], with notable amounts of metals like $\mathrm{Ni}(0.25 \%)$ and $\mathrm{Co}(0.09 \%)$ that are partially oxidised.

The content of heavy metals in this residue has a negative impact on the environment. In recent years, several technologies have been developed with the aim of reducing or removing heavy metals from contaminated media. The physical and chemical processes used to recover metallic species of interest tend to be very costly and generate wastes; hence, microbiological processes have been proposed as an alternative to treat this kind of residue. Prominent among these processes is bioleaching, an inexpensive, clean technology

\footnotetext{
* Corresponding author. Tel.: +34 956016554; fax: +34 956016411. E-mail addresses: gema.cabrera@uca.es (G. Cabrera), josemanuel.montesdeoca@uca.es (J.M. Gómez), ianeyahd@fbio.uh.cu (I. Hernández), ocoto@fbio.uh.cu (O. Coto), domingo.cantero@uca.es (D. Cantero).
}

with low energy requirements. This technology uses the capacity of certain microorganisms to produce acids that are employed as leaching agents to solubilise metal species [3-5].

The recovery of metal species from laterite nickel ores by microorganisms is mainly based on the use of organic acids as leaching agents and these are produced by filamentous fungi [3,6-12]. However, the use of fungi suffers from certain limitations and these include: (i) the need to add organic compounds as a source of carbon and energy to culture the fungi, which increases the cost of future commercial processes [13], (ii) the formation of chelates, which hinders the recovery of dissolved metals [14] and decreases the amount of leached metals, (iii) the phenomenon of biosorption by the fungal biomass [12,15-17] and (iv) electrosorption effects [18], i.e. the attraction of metal cations in solution through electrostatic interactions between the gangue and the cation.

The use of bacteria may avoid some of the drawbacks outlined above. Acidithiobacillus thiooxidans is an acidophilic, chemolithoautotrophic bacterium that oxidises reduced sulphur compounds and produces sulphuric acid $[19,20]$. For this reason, $A$. thiooxidans has been widely used in the bioleaching of low-grade and concentrates of sulphide minerals on both laboratory and industrial scales [21-23]. This bacterium has also been used to solubilise nickel and cobalt from wastes from the mining-metallurgy industry, including lateritic overburden [24] and tailings [25-27]. The aim of the work described here was to evaluate the capacity of $A$. thiooxidans DMS 11478 to recover the heavy metals contained in the residues 
from the CARON process in different configurations - the two-stage batch system and two semi-continuous systems (stirred-tank reactor leaching and column leaching).

\section{Materials and methods}

\subsection{Lateritic residue}

Lateritic residue from the ammonium carbonate technological (CARON) process carried out at the Comandante Ernesto Che Guevara plant (Moa, Holguín, Cuba) was used. The chemical composition of the residue was determined through the total acid digestion of $0.1 \mathrm{~g}$ of residue, previously dried for $12 \mathrm{~h}$ at $105^{\circ} \mathrm{C}$; the mineralogical composition was determined by X-ray diffraction.

The speciation of the metals ( $\mathrm{Ni}, \mathrm{Co}, \mathrm{Fe}, \mathrm{Cr}, \mathrm{Mg}$ and $\mathrm{Mn}$ ) was determined by the sequential extraction process described by Silveira et al. [28] and the metal content in the residual fraction (RF) was calculated by the difference between the total metal content in the residue and its sum in the fractions analysed.

The $\mathrm{pH}$ of the lateritic residue was determined on samples containing $4 \mathrm{~g}$ of solid and $10 \mathrm{~mL}$ of water, measured on the basis of a $1: 2.5$ ratio (soil:water $(\mathrm{w} / \mathrm{v})$ ).

\subsection{Culture medium and microorganism}

A. thiooxidans DMS 11478 was cultured in a $0 \mathrm{~K}$ medium $(\mathrm{pH}$ $\left.3.0,30^{\circ} \mathrm{C}\right)$ with $1 \%(\mathrm{w} / \mathrm{v})$ elemental sulphur as an energy source [24]. Free bacterial population was represented by counting cells in a Neubauer chamber using an optical microscope with a phase contrast (Olympus BH-2).

\subsection{Bioleaching in a two-stage batch system}

During the first stage, $A$. thiooxidans DMS 11478 was cultured for 7 days at $30^{\circ} \mathrm{C}$; the culture was filtered through a nitrocellulose membrane (pore size $0.22 \mu \mathrm{m}$ ). During the second stage, supernatant (bioacid cell-free) from the first stage was added to $10 \mathrm{~g}$ of autoclave-sterilised residue and incubated at $60^{\circ} \mathrm{C}$ for $31 \mathrm{~h}$ at an agitation rate of $150 \mathrm{rpm}$. Both steps were carried out in $250 \mathrm{~mL}$ Erlenmeyer flasks with a $100 \mathrm{~mL}$ working volume. Abiotic control was performed with a sterile $0 \mathrm{~K}$ medium. The experiment was carried out in triplicate.

\subsection{Semi-continuous bioleaching}

\subsubsection{A. thiooxidans culture}

A basic preliminary study on batch systems was carried out in order to determine the best conditions to generate leaching agent from $A$. thiooxidans culture. The inoculum volume [ $10 \%$ and $20 \%(\mathrm{v} / \mathrm{v})]$ and agitation rate $(300 \mathrm{rpm}$ and $500 \mathrm{rpm})$ at an air rate of approximately $1.0 \mathrm{vvm}$ were studied in a stirred-tank reactor (Reactor 1 ) with a $1 \mathrm{~L}$ capacity and a working volume of $800 \mathrm{~mL}$.

When the bacterial culture reached $\mathrm{pH} 1$ under selected conditions [ $20 \%$ inoculum $(\mathrm{v} / \mathrm{v})$ and $500 \mathrm{rpm}$ ], the reactor was fed with a sterile $0 \mathrm{~K}$ medium at a feed rate of $60-70 \mathrm{~mL} /$ day.

\subsubsection{Stirred-tank reactor leaching}

The leaching was performed in a stirred-tank reactor (Reactor 2) with the same configuration as the one used for bacterial growth (Reactor 1) (Fig. 1a). The experiment began with the addition of $80 \mathrm{~g}$ of residue $(0.30-0.50 \mathrm{~mm}$ of particle diameter), $60 \mathrm{~mL}$ of bioacid from Reactor 1 and magnetic agitation at $500 \mathrm{rpm}$. Daily doses of 60-70 mL of bioacid were added to complete an effective volume of $800 \mathrm{~mL}$ of medium. During this initial preparatory phase, the pulp density in the reactor fell as the leaching agent was added until $10 \%$ $(\mathrm{w} / \mathrm{v})$ was reached. Once this level was achieved, $70 \mathrm{~mL}$ of leach liquor was extracted each day and replaced by an equal volume of fresh bioacid.

\subsubsection{Column leaching}

A $60 \mathrm{~mL}$ glass column with $50 \mathrm{~g}$ of residue $(0.75-2.50 \mathrm{~mm}$ particle diameter) was used (Fig. 1b). The bioacid from the biological reactor (Reactor 1 ) was added to the column by a peristaltic pump at rate of $60-70 \mathrm{~mL}$ of bioacid/day and, from this time on, the system was maintained in a semi-continuous regime. In order to increase contact and to improve the solubilisation, after 34 days of the experiment, the leachate was re-circulated in the column by a peristaltic pump at rate of $7 \mathrm{~mL} \mathrm{~min}^{-1}$.

\subsection{Analytical methods}

The $\mathrm{pH}$ of the leachates and cultures was measured with a CRISON (52-02) pH meter with an Ag electrode. Proton concentration was determined by titration with $0.02 \mathrm{~N} \mathrm{NaOH}$; sulphate ion concentration was determined by the turbidimetric method (readings at $450 \mathrm{~nm}$ ) on an HP 8453 spectrophotometer [29]; the samples were centrifuged for $2 \mathrm{~min}$ at $10,000 \mathrm{rpm}$ to avoid interference from other suspended components. Metal concentrations in solution were determined by inductively coupled plasma atomic emission spectroscopy (ICP-AES, IRIS Intrepid). The samples were diluted with $0.14 \mathrm{M} \mathrm{HNO}_{3}$, filtered $(0.45 \mu \mathrm{m})$ and stored at $4{ }^{\circ} \mathrm{C}$ prior to analysis.

\section{Results and discussion}

\subsection{Chemical characterisation of the tailing}

The main mineralogical phases detected (Fig. 2) were: $41.5 \%$ maghemite $\left(\gamma \mathrm{Fe}_{2} \mathrm{O}_{3}\right), 15 \%$ hortonolite $\left(\mathrm{FeSiO}_{4}\right), 10.2 \% \mathrm{Mg}$-chromite $\left[(\mathrm{Mg}, \mathrm{Fe}) \mathrm{Cr}_{2} \mathrm{O}_{3}\right], 7.5 \%$ quartz $\left(\mathrm{SiO}_{2}\right)$ and $9 \%$ chabazite (Mnexchange). These results are similar to those obtained by Rojas and Turro [2] who reported that Fe maghemite oxides constitute the main mineral phases of the residues of CARON from the Ernesto Che Guevara plant (Moa, Cuba).

The six metallic species determined by the sequential treatment ( $\mathrm{Ni}, \mathrm{Co}, \mathrm{Fe}, \mathrm{Cr}, \mathrm{Mg}$ and $\mathrm{Mn}$ ) were mainly associated with crystalline iron oxides (F6) (Table 1). This shows that during the mineral reduction phase in the CARON process, chemical reactions involving oxidation and hydrolysis of the iron ions occurred and resulted in the formation of a solid residue that retained metals such as $\mathrm{Ni}$ and Co, among others [2]. The concentrations of cobalt (absence), iron (4.5\%) and nickel (17.2\%) in the residual or lithogenic fraction (RF) showed that these metallic species had the highest bioavailability in the solid analysis, unlike chromium, which remained in a higher proportion (59.4\%) in that fraction.

\subsection{Bioleaching in two-stage batch system}

The metal solubilisation percentages (Fig. 3) were favoured by the two-stage batch leaching system in which the incubation temperature was increased in the second stage (chemical leaching). As can be seen in Fig. 3, the highest recovery percentages were achieved after the first $6 \mathrm{~h}$ of contact between sulphuric bioacid and residue ( $46.8 \% \mathrm{Co}, 36 \% \mathrm{Mg}, 26.3 \% \mathrm{Mn}$ and $22.3 \% \mathrm{Ni}$ ). From that time on, a significant variation in the recovery of these metal species was not observed. This indicates that the metal leaching stopped when there were still significant amounts of metal left in the processed raw material. This behaviour may be explained by the rapid consumption of the leaching agent after just $6 \mathrm{~h}$ of the experiment [30]. During this $6 \mathrm{~h}$ the leachate $\mathrm{pH}$ doubled from 0.99 to 2.15 and steadily increased until the end of the experiment $(\mathrm{pH} 2.83)$ due to 


\section{a) At. thiooxidans Reactor + stirred-tank reactor leaching}

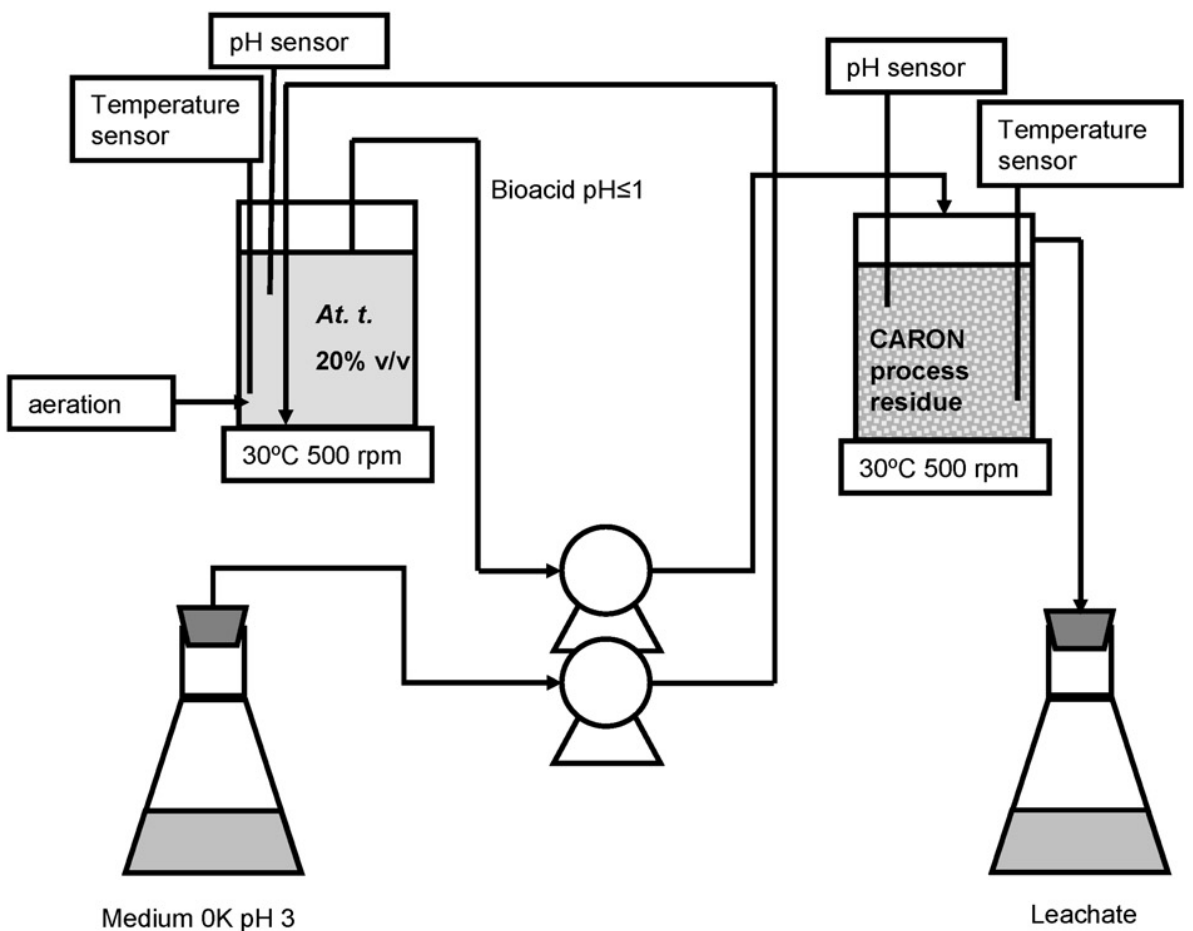

b) At. thiooxidans Reactor + column leaching

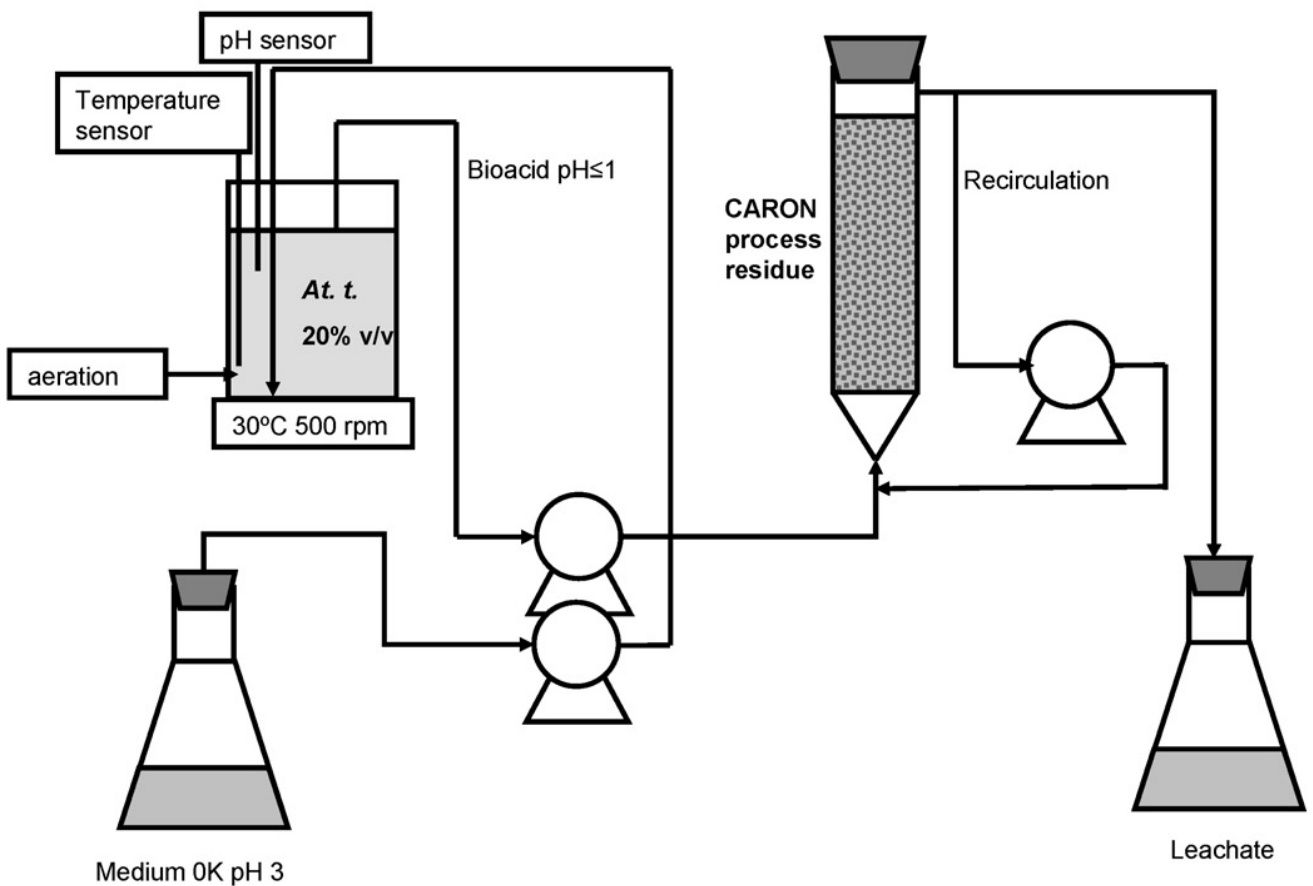

Fig. 1. Diagram of semicontinuous systems. (a) Bioreactor of A. thiooxidans connected with a stirred-tank reactor for leaching metals. (b) Bioreactor of A. thiooxidans connected with a column with recirculation for leaching metals.

the alkaline nature of the processed mining residue $(\mathrm{pH} 8.12)$ and depletion of the leaching agent.

The lowest recovery percentages corresponded to the elements $\mathrm{Cr}$ and $\mathrm{Fe}(2 \%)$, although the Fe cation had the highest concentration detected in the leachates $(8640 \mathrm{ppm})$ since it is the major element in the CARON process residue (Table 1). The behaviour of chromium was consistent with its low bioavailability in the treated residue.
Earlier studies by Hernández et al. [27] showed that bioleaching of $\mathrm{Ni}$ and $\mathrm{Co}$ from CARON process residue with A. thiooxidans in a one-stage batch system was inversely proportional to the increase in pulp density (1\%, 2.5\%, 5\% and 10\%). Leaching was not observed at the highest concentration added (10\%) and the results with $10 \%$ pulp density were identical to the abiotic control. However, the two-stage batch bioleaching with $A$. thiooxidans at the same pulp density (10\%) was significant (Fig. 3), thus demonstrating the supe- 


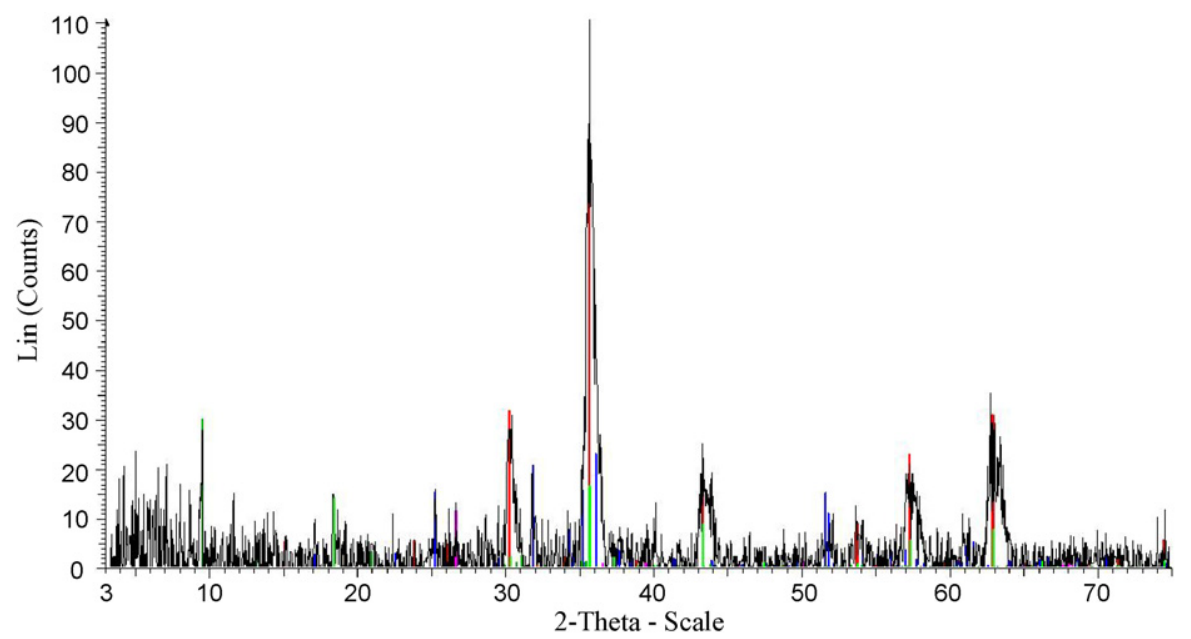

Fig. 2. X-ray diffractogram of the residue. (For interpretation of the references to color in this figure legend, the reader is referred to the web version of this article.) Operations: Background 1.000,1.000 | Import

W01-089-5892 (C) - Maghemite - gamma-Fe21.16031.92 - WL: 1.5406 - Cubic - a 8.34570 - b 8.34570 - c 8.34570 - S-Q $41.5 \%$

W. $01-087-1175$ (C) - Magnesiochromite, syn - (Mg0.984Cr0.016)(Cr1.984Mg0.016)04 - WL: 1.5406 - Cubic - a 8.33780 - b 8.33780 - c 8.33780 - S-Q 10.2 \%

W. $01-071-1670$ (C) - Hortonolite - Fe2SiO4 - WL: 1.5406 - Orthorhombic - a 4.79800 - b 10.39000 - c 6.05500 - S-Q $31.5 \%$

W01-083-2465 (A) - Quartz low, syn - alpha-SiO2 - WL: 1.5406 - Hexagonal - a 4.91480 - b 4.91480 - c 5.40620 - S-Q 7.9\%

W01-085-1278 (C) - Chabazite - (Mn-exchanged), syn - Mn1.9Al3.8Si8.3024 - WL: 1.5406 - Rhombohedral - a 9.34000 - b 9.34000 - c 9.34000 - S-Q $9.0 \%$

Table 1

Composition of the residue determined by a chemical analysis (ppm) and speciation $(\%(\mathrm{w} / \mathrm{v}))$ of the metals present in the tailing.

\begin{tabular}{|c|c|c|c|c|c|c|c|c|}
\hline & \multirow{2}{*}{$\begin{array}{l}\text { Chemical analysis } \\
(\mathrm{ppm} \pm 1 \%)\end{array}$} & \multicolumn{7}{|c|}{ Speciation of the metals $(\%(w / v))$} \\
\hline & & $\begin{array}{l}\text { F1 } \\
\text { Soluble- } \\
\text { exchangeable }\end{array}$ & $\begin{array}{l}\text { F2 } \\
\text { Surface } \\
\text { adsorbed }\end{array}$ & $\begin{array}{l}\text { F3 } \\
\text { Associated } \\
\text { with organic } \\
\text { matter }\end{array}$ & $\begin{array}{l}\text { F4 } \\
\text { Associated } \\
\text { with Mn oxides }\end{array}$ & $\begin{array}{l}\text { F5 } \\
\text { Associated } \\
\text { with poorly } \\
\text { crystalline Fe } \\
\text { oxides }\end{array}$ & $\begin{array}{l}\text { F6 } \\
\text { Associated } \\
\text { with crystalline } \\
\text { Fe oxides }\end{array}$ & $\begin{array}{l}\text { RF } \\
\text { Residual } \\
\text { fraction }\end{array}$ \\
\hline Co & 844 & - & - & - & $2.4 \pm 0.1$ & $12.5 \pm 0.4$ & $67.9 \pm 2.1$ & - \\
\hline $\mathrm{Ni}$ & 3730 & - & - & - & $8.5 \pm 0.3$ & $18.2 \pm 0.5$ & $75.0 \pm 5.2$ & 17.2 \\
\hline $\mathrm{Mg}$ & 46,200 & $\begin{array}{l}2.4 \\
\pm 0.01\end{array}$ & $\begin{array}{l}0.5 \\
\pm 0.06\end{array}$ & $\begin{array}{l}0.2 \\
\pm 0.04\end{array}$ & $2.6 \pm 0.06$ & $6.7 \pm 0.3$ & $65.4 \pm 2.8$ & 22.2 \\
\hline $\mathrm{Fe}$ & 432,000 & - & - & - & $0.3 \pm 0.02$ & $33.1 \pm 1.1$ & $62.1 \pm 3.6$ & 4.5 \\
\hline Mn & 7900 & - & - & - & $12.7 \pm 0.3$ & $5.3 \pm 0.6$ & $59.9 \pm 3.17$ & 22.1 \\
\hline $\mathrm{Cr}$ & 17,600 & - & - & $\begin{array}{l}0.01 \\
\pm 0.006\end{array}$ & - & $7.8 \pm 0.3$ & $32.7 \pm 1.6$ & 59.4 \\
\hline
\end{tabular}

riority of this system since it allows a higher concentration of residue to be treated (pulp density) and reduces the bioleaching time for lower pulp densities from 12 days [27] to 7 days of culture plus $6 \mathrm{~h}$ of leaching.

\subsection{Semi-continuous systems}

\subsubsection{A. thiooxidans culture}

Inoculum concentration and agitation rate are the two decisive parameters in the culture and the production of bioacid by A. thiooxidans cultured in a stirred-tank reactor with elemental sulphur as the energy source [31]. For this reason, a preliminary study was carried out in order to select suitable conditions to generate bioacid to be employed as a leaching agent. Two levels for each parameter were studied; inoculum volume (10\% and 20\% (v/v)) and agitation rate (300 rpm and $500 \mathrm{rpm})$.

The agitation rate was directly related with a decrease in $\mathrm{pH}$. For the lowest agitation rate $(300 \mathrm{rpm})$ the metabolic activity shown by the cultures (oxidation of elemental sulphur) resulted in a low concentration of protons (lower than $0.11 \mathrm{~g} \mathrm{~L}^{-1}$ ) and sulphate ions in solution, which corresponded to the limited drop in the $\mathrm{pH}$ (from 2.2 to 1.5) during the first four days and the subsequent $\mathrm{pH}$ stabilisation. In contrast, the highest agitation rate led to a rapid decrease in $\mathrm{pH}$ to 1.0 , since this rate favoured the homogenisation of the system and bacterial colonisation at the sulphur particles. This difference might be explained by the sedimentation of elemental sulphur in the reactor with the lowest agitation rate, which would limit contact between the bacteria and the energy substrate.

The effect of the $\mathrm{pH}$ decrease in experiments carried out at $500 \mathrm{rpm}$ was augmented with $20 \%(\mathrm{v} / \mathrm{v})$ inoculum, because the presence of higher bacterial population facilitates sulphur-bacteria contact and, as a consequence, the production of bioacid was augmented.

When the $\mathrm{pH}$ reached a value of close to 1.0 in the bioreactor with A. thiooxidans (20\% inoculum, $500 \mathrm{rpm}$ ), a semi-continuous system was established as these chemical conditions are very suitable for leaching metals [25]. The bioreactor was fed with sterile $0 \mathrm{~K}$ 


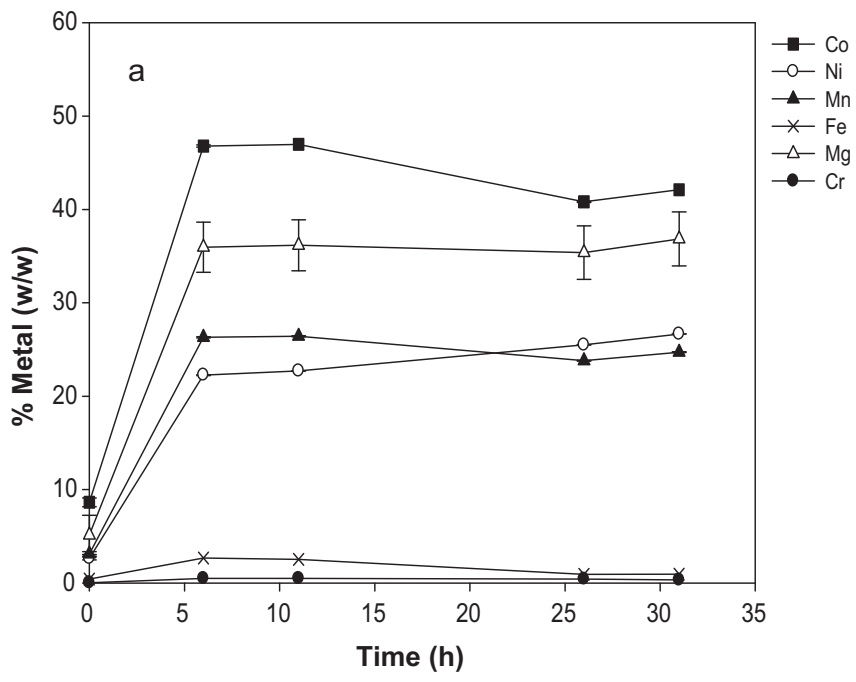

Fig. 3. Percentage of metal solubilised $(w / w)$ in the residue from the CARON process using bioacid in the two-stage batch system $(x \pm \sigma, n=3)$.

medium, which allowed bioacid with a $\mathrm{pH} \leq 1$ to be continuously fed into the stirred-tank reactor (either the leaching or column leaching system).

\subsubsection{Stirred-tank reactor leaching}

The semi-continuous feeding system of Reactor 2 (stirredtank reactor) was connected after 9 days of culture (Reactor 1 ) with the generated bioacid $\left(\mathrm{pH} 0.9,22 \mathrm{gL}^{-1} \mathrm{SO}_{4}, 0.4 \mathrm{gL}^{-1} \mathrm{H}^{+}\right.$, $1.2 \times 10^{9}$ cell mL$^{-1}$ ) (Fig. 4). During the first days of bioleaching in the reactor, the initial solid-liquid ratio $(80 \mathrm{~g}$ residue: $70 \mathrm{~mL}$ bioacid) was diminished through the addition of $60 \mathrm{~mL}$ of bioacid/day until day 13 , when the pulp density was stabilised $(10 \%$ $(\mathrm{w} / \mathrm{v})$ ). At that point, $26 \% \mathrm{Co}, 20 \% \mathrm{Ni}, 5 \% \mathrm{Fe}, 33 \% \mathrm{Mg}$ and $21 \% \mathrm{Mn}$ had been solubilised (Fig. 5).

The presence of $\mathrm{Mg}$ ions in fractions F1-F3 of the sequential extraction protocol (Table 1) demonstrates the high bioavailability of this element compared with the other metallic species analysed. The precipitation of this metal at 12 days may be due to the formation of compounds with other dissolved metallic ions that cause precipitation by supersaturation between the $\mathrm{Mg}$ and Fe ions.

Once a pulp density of $10 \%(\mathrm{w} / \mathrm{v})$ had been reached (day 13 ), $70 \mathrm{~mL}$ of the bioacid leaching liquor was replaced every day by fresh

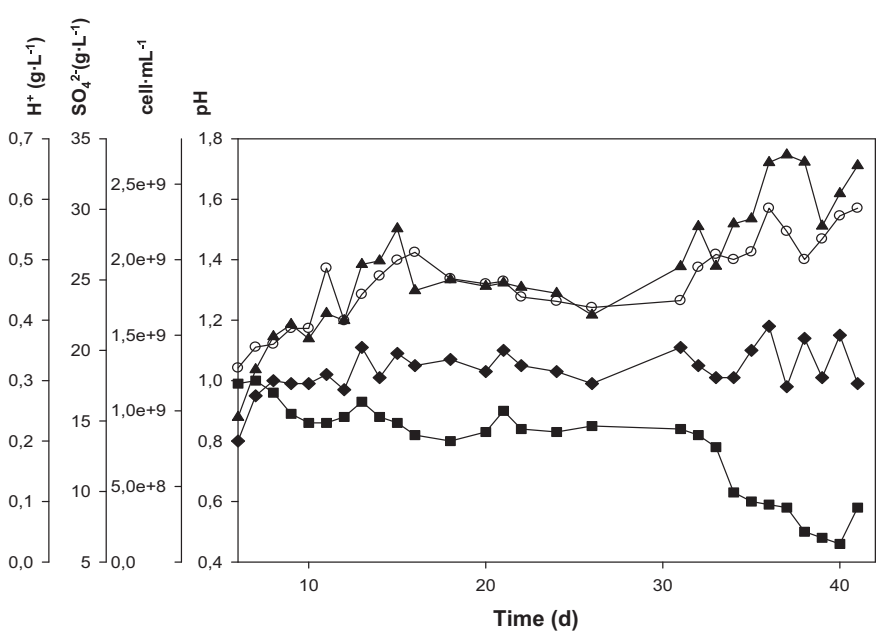

Fig. 4. Evolution of cell concentration ( $\downarrow)$, production of protons $(\bigcirc)$, sulphate $(\boldsymbol{\Delta})$ and $\mathrm{pH}(\mathbf{\square})$ for a Acidithiobacillus thiooxidans culture in a semi-continuous regime.

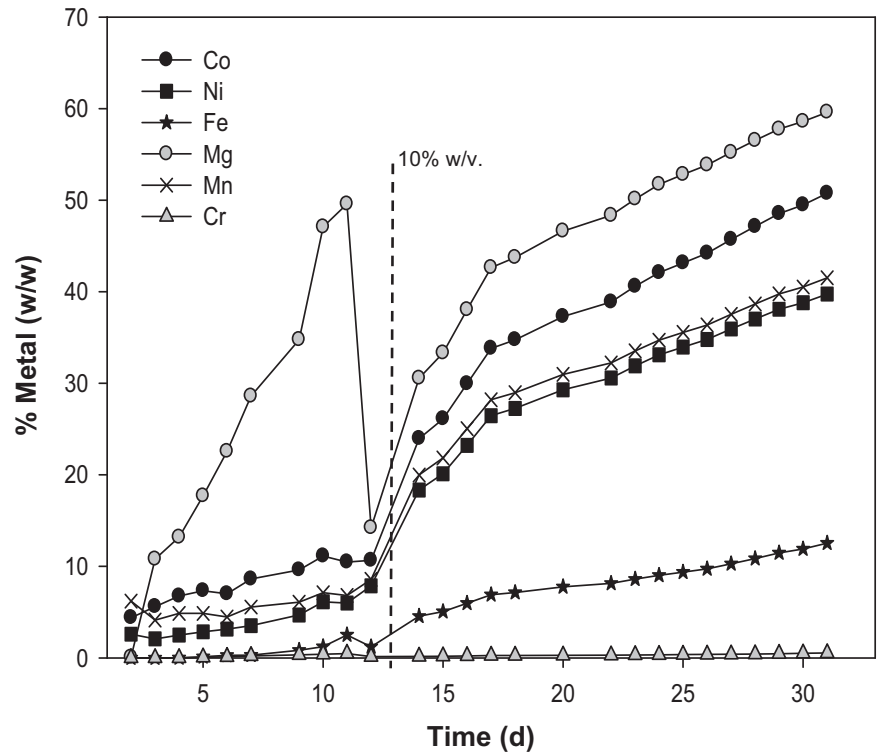

Fig. 5. Concentration of metal solubilised during the stirred-tank reactor leaching with a culture of $A$. thiooxidans from Reactor 1.

bioacid. This operation, which lasted 18 days, allowed the recovery of nearly double the amount of $\mathrm{Ni}, \mathrm{Co}, \mathrm{Mn}$ and $\mathrm{Mg}$ and prevented depletion of the leaching agent, a phenomenon that was seen during the second stage of leaching at the Erlenmeyer level. By the end of the experiment, $60 \%$ of the $\mathrm{Mg}$ and between 40 and $50 \%$ of the $\mathrm{Co}$, $\mathrm{Mn}$ and Ni had been recovered. However, the methodology applied was still insufficient to solubilise Fe (12\%), due the high concentration present in the residue, and $\mathrm{Cr}(1 \%)$, since this metal is the least bioavailable in the residue due to its high concentration in the residual or lithogenic fraction (Table 1 ).

A comparison between the results obtained in the two-stage batch system and the semi-continuous system shows higher levels of solubilisation in the latter case; however, a longer operation time was required. It is feasible that the magnetic agitation of the leaching residue during this study was insufficient to retain the amount of solid added to the reactor in suspension, since CARON process residue is typically a very fine powder that adheres readily to the reactor walls, causing a non-homogeneous, low-efficiency system [32].

\subsubsection{Column leaching}

Although stirred-tank reactor bioleaching is a technology used in the mining industry [33], the high manufacturing and maintenance costs limit its current use to bioleaching concentrates [34,35] and biooxidation $[21,36,37]$. One of the largest capital investments in industrial processes and highest operating costs are the stirrers [38] needed by the reactors to keep solids in suspension and facilitate mass transfer in the system.

In an effort to overcome the limitations outlined above, column leaching was evaluated as an alternative to the stirred-tank reactor operation. In this system, CARON process residue with a higher particle size was used $(0.75-2.50 \mathrm{~mm}$ particle diameter). Small particles could favour the contact between bioacid and metal but particles of this size could settle and clog the conventional pile leaching process, resulting in slow percolation rates and poor recovery of metals [38]. As a result, the system was operated with a higher particle size and recirculation to promote the residue-bioacid contact.

A. thiooxidans culture was maintained in a discontinuous regime for eleven days until it reached a $\mathrm{pH}$ close to 0.8 . At this moment, a semi-continuous system was established in a column with $80 \mathrm{~g}$ 


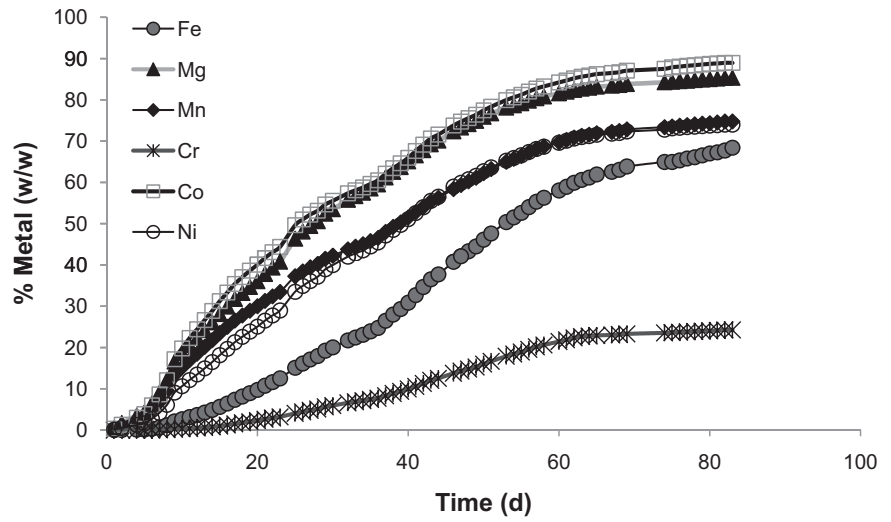

Fig. 6. Evolution of metals solubilised in the column leaching with CARON process residue ( $83 \%$ pulp density).

of residue which was fed with bioacid $\left(30 \mathrm{~g} \mathrm{~L}^{-1} \mathrm{SO}_{4}, 0.58 \mathrm{~g} \mathrm{~L}^{-1} \mathrm{H}^{+}\right.$, $10^{9}$ cell $\left.\mathrm{mL}^{-1}\right)$. From this time on, there was a steady rise in $\mathrm{H}^{+}$ concentration and, consequently, the $\mathrm{pH}$ dropped as the alkaline residue was acidified during this period, a situation that benefited the gradually rising concentration of metals in solution from day one - except for $\mathrm{Fe}$ and $\mathrm{Cr}$, which began to leach at 7 and 14 days, respectively (Fig. 6). After 31 days of leaching, approximately $50 \%$ of the $\mathrm{Mg}$ and $\mathrm{Co}$ and $40 \%$ of the $\mathrm{Mn}$ and $\mathrm{Ni}$ had been solubilised, values similar to those obtained in the reactor leaching for the same period (Fig. 5), although the particle size of the residue treated was higher.

After 34 days of leaching, recirculation of bioacid in the column was started in order to increase contact between the bioacid and residue. The possible adhesion of $A$. thiooxidans, from the biological reactor, to the solid residue and its presence in the bioacid in the column explains the increasing proton concentration and decreased $\mathrm{pH}$ of the leach liquor, which remained practically constant in the recirculation phase (Fig. 7) with a continuous generation-consumption of the bioacid. This system favoured the solubilisation of metals and had a marked effect on the leaching of $\mathrm{Fe}(22.7 \%)$ and $\mathrm{Cr}(6.6 \%)$ ions, values that had not been achieved with the previous systems tested.

The high level of association of the metals to the Fe oxides in the CARON process residue may explain the slow leaching of Fe with respect to $\mathrm{Co}, \mathrm{Ni}, \mathrm{Mg}$ and $\mathrm{Mn}$, a situation that required a higher concentration of the leaching agent and increased contact time for its solubilisation. This explanation is supported by the presence of iron oxides as major phases in the mineralogical composition of

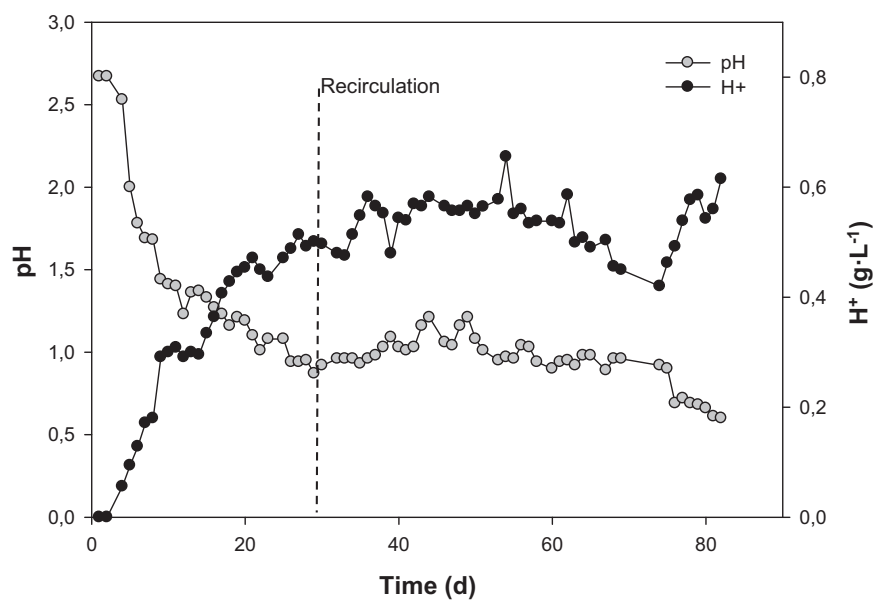

Fig. 7. Evolution of the concentration of proton $(\bigcirc)$ and pH $(\boldsymbol{\square})$ in column leaching. the residue. The system tested (column leaching with recirculation) seems to favour the leaching of iron present in these oxides.

Given that the recovery percentages at 65 days $(86 \% \mathrm{Co}, 83 \% \mathrm{Mg}$, $72 \% \mathrm{Mn}$ and $\mathrm{Ni}, 62 \% \mathrm{Fe}$ and $23 \% \mathrm{Cr}$ ) were close to those achieved after 83 days of bioleaching ( $89 \% \mathrm{Co}, 85 \% \mathrm{Mg}, 75 \% \mathrm{Mn}, 74 \% \mathrm{Ni}, 68 \% \mathrm{Fe}$ and $25 \% \mathrm{Cr}$ ), a period of 65 days could be considered as the optimum time as the work during the last twenty three days in the latter system is not advantageous.

\section{Conclusions}

The three leaching methods used in this study (two-stage batch, stirred-tank reactor and column) are feasible for the treatment of residue at a pulp density equal to or greater than $10 \%(\mathrm{w} / \mathrm{v})$. Bioleaching is an attractive method from the hydrometallurgical point of view for residue from the CARON process, which cannot be treated for recycling because of its mineralogical composition. The results of this study demonstrate the feasibility of using $A$. thiooxidans in treating oxidised residue with an alkaline $\mathrm{pH}$ (8.0) and high pulp densities. The percentages of recovery in the column bioleaching system and stirred-tank reactor system were similar at 31 days of leaching, with approximately $50 \%$ of the $\mathrm{Mg}$ and $\mathrm{Co}$ and $40 \%$ of the $\mathrm{Mn}$ and Ni being recovered. The column leaching system with recirculation of the bioacid allowed the solid-liquid ratio to be significantly increased, the $\mathrm{pH}$ of the system to be maintained at levels below 1.5 and led to the solubilisation of larger amounts of the metals present.

Future work will be focused on the column bioleaching system - specifically establishing recirculation of bioacid before 34 days, once $\mathrm{pH}$ and proton concentration are stabilised in the column (day 20 approximately). This modification could contribute to solubilise the metals and to reduce the operation time.

\section{Acknowledgements}

The authors of this study thank the CYTED programme for the funding received for the project: "Bioprocesses to Reduce and Remediate Environmental Pollution (BIORECA)", which allowed this study to be conducted.

\section{References}

[1] D. Kempthorne, M.D. Myers, Mineral Commodity Summaries U.S., Geological Survey, Washington, 2008, pp. 52-54, 114-115.

[2] A. Rojas, A. Turro, Composición mineralógica de las colas del proceso CARON en Moa, Holguín, Cuba, Miner. Geol. 1 (2003) 3-4.

[3] K. Bosecker, Bioleaching: metal solubilization by microorganisms, FEMS Microbiol. Rev. 20 (1997) 591-604.

[4] J.A. Brierley, C.L. Brierley, Present and future commercial applications of biohydrometallurgy, Hydrometallurgy 59 (2001) 233-239.

[5] C.L. Brierley, Biohydrometallurgy: what is its future? Adv. Mater. Res. 71-73 (2009) 3-10.

[6] K. Bosecker, Leaching of lateritic nickel ores with heterotrophic microorganisms, in: R.W. Lawrence, B.M.R. Branion, H.G. Ebner (Eds.), Proceedings of the 6th International Symposium Biohydrometallurgy, Oxford, 1986, pp. 367-382.

[7] K. Bosecker, Bioleaching of valuable metals from silicate ores and silicate waste products, in: J. Sally, R.G.L. McCready, P.L. Wichlacz (Eds.), Biohydrometallurgy, 1989, pp. 15-24.

[8] P. Tzeferis, Leaching of low-grade hematitic laterite ore using fungi and biologically and metabolites, Int. J. Miner. Process. 42 (1994) 267-283.

[9] M. Valix, J. Tang, W. Cheung, Fungal bio-leaching of low grade laterite ores, Miner. Eng. 14 (2001) 197-203.

[10] O. Coto, N. Bruguera, L. Abín, J. Gamboa, Y. Goméz, Bioleaching of Cuban nickeliferrous serpentinite, in: V.S.T. Ciminelli, O.O. Garcia (Eds.), Biohydrometallurgy. Fundamentals, Technology and Sustainable Development. Part A, Elsevier, Amsterdam, 2001, pp. 175-182.

[11] O. Coto, D. Gutiérrez, L. Abín, J. Marrero, K. Bosecker, Influence of $\mathrm{pH} \mathrm{Mg}^{2+}$ and $\mathrm{Mn}^{2+}$ on the bioleaching of nickel laterite ore using the fungus Aspergillus niger O5, in: M. Tsezos, A. Hatzikioseyian, E. Remoundaki (Eds.), Biohydrometallurgy: A Sustainable Technology in Evolution. Part 1, University of Athens, Greece, 2003, pp. 124-134.

[12] O. Coto, M. Peguero, L. Abín, N. Bruguera, J. Marrero, K. Bosecker, Bioleaching of laterite by Aspergillus niger strain 05, an acidophilic, nickel and cobalt resistant 
fungus, in: S.T.L. Harrison, D.E. Rawlings, J. Petersen (Eds.), Proceedings of the 16 th International Biohydrometallurgy Symposium, Cape Town, South Africa, 2005, pp. 357-364.

[13] K. Bosecker, Microbial leaching in environmental clean-up programmes, Hydrometallurgy 59 (2001) 245-248.

[14] A. Deeptana, M. Valix, Recovery of nickel and cobalt from organic acid complexes: adsorption mechanisms of metal-organic complexes onto aminophosphonate chelating resin, J. Hazard. Mater. B 137 (2006) 925-933.

[15] A. Kapoor, T. Viraraghavan, Biosorption of heavy metals on Aspergillus niger: effect of pretreatment, Bioresour. Technol. 63 (1997) 113-119.

[16] B. Volesky, Biosorption for the next century, in: A. Ballester, R. Amils (Eds.), Biohydrometallurgy and the Environment Toward the Mining of the 21st Century. Part A, Elsevier Sciences, Amsterdam, 1999, pp. 161-170.

[17] J. Wang, C. Chen, Biosorbents for heavy metals removal and their future, Biotechnol. Adv. 27 (2009) 195-226

[18] M. Valix, F. Usai, R. Malix, The electrosorption properties of nickel on laterite gangue leached with an organic chelating acid, Miner. Eng. 14 (2001) 205-215.

[19] Y. Konishi, S. Asai, N. Yoshida, Growth kinetics of Thiobacillus thiooxidans on the surface of elemental sulfur, Appl. Environ. Microbiol. 61 (1995) 3617-3622.

[20] A. Schippers, Microorganisms involved in bioleaching and nucleic acid-based molecular methods for their identification and quantification, in: E. Donati, W. Sand (Eds.), Microbial Processing of Metal Sulfides, Springer, The Netherlands, 2007, pp. 3-33.

[21] D.E. Rawlings, H. Tributsch, G.S. Hansford, Reasons why 'Leptospirillum'-like species rather than Thiobacillus ferrooxidans are the dominant iron-oxidizing bacteria in many commercial processes for the biooxidation of pyrite and related ores, Microbiology 145 (1999) 5-13.

[22] N. Okibe, M. Gericke, K.B. Hallberg, D.B. Johnson, Enumeration and characterization of acidophilic microorganisms isolated from a pilot plant stirred-tank bioleaching operation, Appl. Environ. Microbiol. 69 (2003) 1936-1943.

[23] V. Zepeda, F. Galleguillos, V. Urtuvia, J. Molina, C. Demergasso, Comparison between the bacterial populations from solutions and minerals in $1 \mathrm{~m}$ test columns and the industrial low grade copper sulphide bioleaching process in the Escondida Mine, Chile, Adv. Mater. Res. 71-73 (2009) 63-66.

[24] I. Hernández, F. Galizia, O. Coto, E. Donati, Reduction of heavy-metal content in overburden material by bacterial action, Adv. Mater. Res. 71-73 (2009) 653-656.
[25] O. Coto, F. Galizia, E. González, I. Hernández, J. Marrero, E. Donati, Cobalt and nickel recoveries from lateritic tailings by organic and inorganic bioacids, Adv. Mater. Res. 20-21 (2007) 107-110.

[26] O. Coto, F. Galizia, I. Hernández, J. Marrero, E. Donati, Cobalt and nickel recoveries from lateritic tailings by organic and inorganic bioacids, Hydrometallurgy $94(2008) 18-22$

[27] I. Hernández, F. Galizia, O. Coto, E. Donati, Improvement in metal recovery from laterite tailings by bioleaching, Adv. Mater. Res. 71-73 (2009) 489-492.

[28] M. Silveira, L. Alleoni, G. O'Connor, A. Chang, Heavy metal sequential extraction methods-a modification for tropical soils, Chemosphere 64(2006) 1929-1938.

[29] L.S. Clesceri, A.E. Greenberg, R.R. Trusell, Standards Methods for the Examination of Water and Wastewater, 17th ed., APHA/AWWA/WPCF, Washington 1989.

[30] Y.Xu, Y. Xie, L. Yan, R. Yang, A new method for recovering valuable metals from low-grade nickeliferous oxide ores, Hydrometallurgy 80 (2005) 280-285.

[31] Y.S. Wang, Z.Y.Pan, J.M. Lang, J.M. Xu, Y.G.Zheng, Bioleaching of chromium from tannery sludge by indigenous Acidithiobacillus thiooxidans, J. Hazard. Mater. 147 (2007) 319-324.

[32] V. Bosio, M. Viera, E. Donati, Integrated bacterial process for the treatment of a spent nickel catalyst, J. Hazard. Mater. 154 (2008) 804-810.

[33] G. Olson, J. Brierley, C. Brierley, Bioleaching review part B: progress in bioleaching: applications of microbial processes by the minerals industries, Appl. Microbiol. Biotechnol. 63 (2003) 249-257.

[34] P. Craven, P. Morales, The Billiton-Codelco strategy for commercializing copper bioleaching, in: Randol Copper Hydromet Roundtable 2000, Randol International Ltd., Golden, Colorado, 2000, pp. 119-126.

[35] C.L. Brierley, A.P. Briggs, Selection and sizing of biooxidation equipment and circuits, in: A.L. Mular, D.N. Halbe, D.J. Barret (Eds.), Mineral Processing Plant Design, Practice and Control, Society of Mining Engineers, Littleton, Colorado, 2002, pp. 1540-1568.

[36] L. Cancho, M.L. Blazquez, A. Ballester, F. Gonzalez, J.A. Munoz, Bioleaching of a chalcopyrite concentrate with moderate thermophilic microorganisms in a continuous reactor system, Hydrometallurgy 87 (2007) 100-111.

[37] J.R. Van Deventer, B. Gigas, New Biox ${ }^{\circledR}$ agitator concept textwork, Adv. Mater. Res. 71-73 (2009) 461-464.

[38] O. Rzhepishevska, L. Börje, O. Tuovinen, M. Dopson, Bioleaching of sulfidic tailing samples with a novel vacuum-positive pressure driven bioreactor, Biotechnol. Bioeng. 92 (2005) 559-567. 